$16^{\text {th }}$ International Conference on

AEROSPACE SCIENCES \& AVIATION TECHNOLOGY,

ASAT - 16 - May 26 - 28, 2015, E-Mail: asat@ mtc.edu.eg Military Technical College, Kobry Elkobbah, Cairo, Egypt

Tel : +(202) 24025292-24036138, Fax: +(202) 22621908

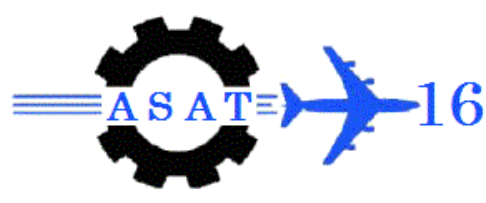

\title{
Numerical Investigation on the Effect of Using Mixtures of Natural Gas and Aviation Fuel on Flame Characteristics of Swirl Gas Turbine Combustor
}

Ahmed I. Farag ${ }^{*}$, Tarek M. Belal ${ }^{\dagger}$, and Akram E. Zeid

\begin{abstract}
The present paper is directed to study aviation fuel combustion compared to that of natural gas in a gas turbine swirl Combustor. Finite-volume based CFD commercial package ANSYS Fluent 12 is used for the present investigation. The SST $k-\omega$ model is used to simulate turbulence. The non-premixed combustion model is used to simulate the reacting flow. Combustion of natural gas is sooty in nature. Thus, soot distribution in the combustor is investigated numerically using the two step soot model. Simple expressions for the soot formation and oxidation rates were employed. The radiation heat transfer equation was solved using the P-1 radiation model. The formation of thermal NO from molecular nitrogen was modeled and the prompt NO was also included in the computations. CFD modeling is validated against experimental temperature measurements for a swirl combustor when firing natural gas as referred to a previous paper. Using the SST-K- $\omega$ for predicting gas temperature distributions satisfy reasonable agreement with the experimental temperature measurements, except near the combustor upstream and in the vicinity of the combustor axis.
\end{abstract}

Keywords: Compressed natural gas, Aviation fuel, Gas Turbine Combustor, Temperature distributions and CFD Modeling, Swirl flame, Turbulence-chemistry interaction, model Validation.

\begin{tabular}{llll} 
& & \multicolumn{2}{l}{ Nomenclature } \\
A/F & Primary air to fuel mass ratio & RZ & Recirculation Zone \\
S & Swirl Number & RFZ & Reverse Flow Zone \\
L & Combustor Length & r/R & Dimensionless Radial Distance \\
D & Combustor Diameter & X/D & Dimensionless Axial Distance
\end{tabular}

\footnotetext{
*Ahmed I. Farag, Dr. Colonel Engineer, Lecturer free, Email: enfarag1611@yahoo.com

†Tarek M. Belal, Dr. college of engineering, pharos univ., Email: tarek_belal@yahoo.com

$\star$ Akram E. Zeid, Dr. College of maritime transportation, Email: akram zaid 22@ yahoo.com
} 


\section{1-Introduction:}

A gas turbine is one of the most reliable devices for power generation and aircraft applications. Gas turbine combustors are responsible for the combustion process that provides energy to the turbine section. Challenges facing the combustor design are related to its wall cooling, flame stability and emissions control. These features determine the gas turbine operational range, durability, cost and emissions characteristics [1,2]. The combustion process within a gas turbine engine is a complex interaction between flow aerodynamics, chemical kinetics, and air-fuel mixing. Each of these processes plays an essential role in the combustor design and has been studied extensively over years. Comprehensive previous works regarding the flow aerodynamics, the combustion process, fuels used in gas turbines are provided.

Natural Gas is a naturally occurring mixture consisting mainly of methane. The average heating value will depend on the mixtures supplies, and therefore can vary from the typical values [3]. Natural gas has been increasingly used as a fuel such as in gas turbines for power generation and in natural gas vehicles (NGVs) as an alternative fuel. However, significant amounts of pollutant emissions in gas turbine applications, particularly $\mathrm{NO}_{\mathrm{x}}$ and unburned methane, can be pointed out as the major drawbacks of its utilization [4]. Aviation fuels are used for powering aircraft engines where there are two main grades of aviation fuels in use in aviation field: Jet A and Jet A-1, both are kerosene type fuels $[5,6]$.

Many studies review using CFD analysis in gas turbine combustors used in power generation, aero-engines and combustion industries [7-11]. New computational methods are developed for solving problems in different engineering fields. One of these fields is gas turbines where the challenge is to increase gas turbine efficiency and to reduce pollutant emissions. Combustion chambers in gas turbines need to be improved for this reason. Therefore, many experimental and numerical methods are performed to optimize the gas turbine combustion chamber design.

Pollutant emissions from gas turbines have been of great concern for several decades. NOx from aircraft engines emits directly to the upper atmosphere layers which contributes to depletion of ozone layer [12]. New fuels are considered as alternative to petroleum based fuels. Some other fuels are preferred to mix with petroleum fuels, because its properties are closer to those of the latter. Studies of the effect of mixtures of Jet-A and other fuels on emission characteristics of a gas turbine combustion are performed by Mendez et al. Butanol from $25 \%$ to $75 \%$ by volume, were mixed with jet-a and used as an alternative fuel. Specific fuel consumption, turbine inlet temperature, exhaust gas temperature, and emission characteristics were investigated. NOx and CO emission were lowered for butanol-blends compared to those with Jet-A [13-18].

All methods of emissions reduction is a "trade-off" between $\mathrm{CO}$ and UHC on one side and NOx on the other side [19]. The majority of NOx emissions are generated in the highest temperature regions within the combustor taking place in the primary zone before gases diluted [2•]. Technologies have been developed to decrease these pollutant emissions simultaneously, the key of which is to avoid stoichiometric reactions, to operate at temperatures sufficient for CO oxidation but does not enhance NOx zone $\left[r^{r} 1, r^{r}\right]$.

Flow aerodynamics plays a vital role in design and performance of gas turbine Engines. Good mixing is essential for high burning rates and minimizing pollutant emissions. Obtaining a satisfactory temperature distribution in the exhaust is very dependent on mixing [ $r$ r ]. Introducing a swirl flow in gas turbine engine proved a promising way in reducing emissions. $\left[\begin{array}{r}r \\ -\end{array} \mathrm{Y} O\right.$. Different methods that generate swirl are to impart a tangential or azimuthal velocity component to the flow. The degree of swirl can be characterized by a parameter called the swirl number (S), which is defined as the ratio of the axial flux of angular momentum to the 
axial flux of axial momentum times the exit radius [ [ $\left.{ }^{\top}\right]$. When swirl number is increased, a strong coupling develops between the axial and tangential velocity components. A point is reached when the adverse pressure gradient along the jet axis cannot be further overcome by the kinetic energy of the fluid particles in the axial direction, and a reverse flow zone is formed in the central portion of the jet $[2 \vee, 2 \wedge]$.

Chigier and Chervinsky [29] found that the reverse flow zone is formed beyond a swirl number $>0.6$. Tangirala et al $\left[3^{\circ}\right]$ studied the effect of swirl number variations and showed that increasing the swirl improves mixing and flame stability for swirl numbers up to 1.0. Further increase in swirl reduced turbulence levels and flame stability. The recommended swirl number falls in the range of 0.6 up to 1.0. In combustion, the gas axial velocity is higher compared to the isothermal case due to the gas expansion [r)]. Also, the strength of the recirculation zone is for the reacting case, and the overall length of the recirculation zone is shorter compared to the non-reacting case [ $\left.{ }^{r} r, 33\right]$.

Air Pollutants become a concern, especially NOx due to its contribution to smog, acid rain, and depletion of ozone layer. The main sources of nitric oxide emissions in combustion are: 1-Oxidation of molecular nitrogen via the thermal NO mechanism 2-Formation of NO via the prompt mechanism and 3-Oxidation of nitrogen-containing compounds in the fuel via the fuel-bound NO mechanism. These sources depend on operating conditions and the fuel types [34].

Kenbar et al [35] reported that increased swirl produced locally higher NOx concentrations within the central recirculation zone but it did not contribute significantly to overall NOx emissions. Chen and Driscoll [36] reported that increasing the swirl intensity does not significantly affect NOx. Schmittel at al [37], using natural gas diffusion flames with found that NOx emissions decreased significantly with increasing the swirl number. This is due to a higher recirculated mass flow rate through the recirculation zone which led to decreasing the residence time within that zone with increasing the swirl number and so NOx is reduced. Mellor et al [38] measured the temperature and species within a combustor using liquid propane at an overall equivalence ratio of 0.217 . They observed that high NOx concentrations were found along the centerline in the region thought to be within the recirculation zone. Claypole, et al [39] studied the influence of swirl levels on the aerodynamics and NOx emissions using natural gas with $10 \%$ excess air. They concluded that the recirculation zone, despite its long residence time and moderate temperatures, did not contribute to NOx.

One concern to a gas turbine combustor is to minimize CO levels. Significant amount of CO is produced due to lack of oxygen or due to dissociation of $\mathrm{CO} 2$ in fuel-lean combustion, or due to low combustion temperature in lean-fuel reacting flow cases. Usually, in gas turbine combustion, $\mathrm{CO}$ increases rapidly in the flame zone to a maximum value, followed by a slower decrease toward the equilibrium concentration. Correa [40] pointed out that carbon monoxide produced in the flame stabilization zone can survive the flame and must be oxidized in the turbulent post-flame gas, introducing a much greater dependence on aerodynamics than is the case for NO, (in lean premixed flames). He also referred that the reason for $\mathrm{CO}$ emissions to increase within the flame stabilization zone because $\mathrm{CH}$ species react much more rapidly than $\mathrm{CO}$ with oxidizing radicals. Thus $\mathrm{CO}$ cannot be oxidized until the gas exits the stabilization region and the $\mathrm{CH}$ levels drop.

Baulch and Drysdale [41] evaluated the reaction rate of this mechanism and concluded that this reaction path is important in combustion systems where it acts as the principle source of $\mathrm{CO} 2$ and plays a major role in determining the yield of $\mathrm{CO}$. Bowman [42] cited that for temperatures below $1000 \mathrm{~K}$, the reaction rate constant $(\mathrm{k})$ is independent of temperature. 
However, at higher temperatures in excess of $1500 \mathrm{~K}$, the rate coefficient $\mathrm{k}$ exhibits significant temperature dependence. Correa referred that the rate of $\mathrm{CO}$ oxidation is reduced by more than two orders of magnitude between flame-like $(1800 \mathrm{~K})$ and combustor liner-like (1100-1200K) temperatures. An alternative reaction path that might have significance on CO oxidation at lower temperatures (1000-1500 K) was suggested by Westenberg and de Ha [43].

Natural gas has been used as an alternative to petroleum fuels to reduce their consumption and to prolong their life and as potential for reducing exhaust emissions. It has the ability of reducing exhaust green gas emissions. It is also used for safety handling and secured operations than that of using petroleum fuels. From previous literature it is clear that researches about aviation fuel combustion are not enough. Also the shortage in production of petroleum based fuels is increasing which stimulate the study of alternative fuel and fuel mixtures. Therefore, the present paper is directed to study the effect of natural gas and jet-A mixtures on combustion characteristics in aircraft gas turbines.

Different ratios of natural gas (mainly methane) to jet-A aviation fuel are used. The study is started using natural gas only and then jet-A fuel. Then the study was extended to use $10 \%$ methane up to $75 \%$ and then results are compared with the 100 methane. The total air to fuel ratio in the gas turbine combustor may exceed 100. Air entering the combustor is divided into two streams, primary air (combustion air) and secondary air (20\% of total air). The present study is concerned about combustion air and the effect of secondary air is not considered since the combustor used is water cooled. In this study primary air to fuel ratio is about of 40 which results in appropriate flame size for the model combustor.

\section{2-CFD Modeling}

This paper is directed to investigate numerically combustion characteristics of aviation and natural gas fuels in a gas turbine combustor. The present study is started to investigate the effect of swirl number on the cold flow field in the combustor (Axial velocity distributions and the RFZ). Then the effect of swirl number on flme sharacteristics in terms of temperature maps will is investigated using natural gas fuel. Finally the investigation will be extended to the effect of using mixtures of natural gas and aviation fuels on combustion and emission characteristics. A test combustor attached wth an air at its upstream end is used. Different air wirlers are used to study the effect of swirl number on flow field and combustion characteristics. The swirlers used have same blockage ratio of 0.72 (inner diameter $=36 \mathrm{~mm}$ and outer diameter $=50 \mathrm{~mm}$ ) with different vane angles. The swirlers vane angles used are of $30^{\circ}, 40,45^{\circ}$, and $52^{\circ}$ to produce swirl numbers of $0.5,0.7,0.9$ and 1.1 , respectively since the swirl number (S) is defined by the following formula as given in reference [26].

$$
S=\frac{2}{3}\left\{1-\left(\frac{r_{i}}{r_{o}}\right)^{3}\right\} /\left\{1-\left(\frac{r_{i}}{r_{o}}\right)^{2}\right\} \tan \alpha
$$

Three dimensional models in the CFD package Ansys Fluent 12 are used to simulate the isothermal and combustion flows in the present combustor. Modeling results will be validated by comparing computational results obtained from $100 \%$ natural gas combustion with experimental results obtained from natural gas combustion.

\subsection{Creating the model geometry and the computational mesh}

The geometry of the combustor and the corresponding computational mesh are shown in figures $(1,2)$, respectively. The combustor model geometry is performed and the mesh is generated using Gambit 2.3 program [44]. The combustor dimensions are $100 \mathrm{~cm}$ in length and $20 \mathrm{~cm}$ diameter. The combustor outlet is ended by a conical restriction end with a 
length of $10 \mathrm{~cm}$ and exit diameter of $5 \mathrm{~cm}$. Combustion air is introduced through the swirler vanes. The fuel enters through a simple nozzle of $1 \mathrm{~cm}$ diameter located coaxially at the center of the air swirler. The computational mesh of the combustor geometry and the swirler (45 degree) is shown in figure (2). The mesh consists of about 300,000 tetrahedral cells. Mesh cells sizes, density and distribution are essential for numerical solutions. Numerical accuracy can be improved by careful distribution of grid cell sizes which make compromise between computational time and numerical accuracy, removing the need for more complicated meshes. The mesh has high cells density at zones of interest such as the swirler and the combustor upstream and low density in other zones of less interest. Applying the quality criteria for tetrahedral mesh cells in fluent 12, the grid quality is checked and a maximum cell squish are shown to be 0.72 and a maximum cell skew less of 0.75 .

\subsection{Boundary conditions}

Boundary conditions are important for numerical solution. Inlet boundary conditions are inlet air mass flow rate, fuel mass flow rate and outlet flow at the combustor exit section. The boundary conditions of combustion air are: inlet mass flow rate of $0.02 \mathrm{~kg} / \mathrm{s}$, inlet temperature of $300 \mathrm{~K}$, turbulence intensity of $15 \%$, and the hydraulic diameter is $2.8 \mathrm{~cm}$. Boundary conditions of the fuel are: inlet mass flow rate, $0.0005 \mathrm{~kg} / \mathrm{s}(\mathrm{AF}=40)$, temperature of $300 \mathrm{~K}$, turbulence intensity of $10 \%$, mean mixture fraction of 1.0 . The boundary condition of the outlet of combustion is defined by providing pressure value. The relative pressure is taken zero gage pressure (Pascal), radial equilibrium pressure distribution, exit temperature of about $1000 \mathrm{~K}$ and exit hydraulic diameter of $5 \mathrm{~cm}$, turbulence intensity ratio of 10 , and hydraulic diameter of $5 \mathrm{~cm}$.

\subsection{Modeling methodology}

The finite volume and the first-order upwind methods are used to solve the governing equations. The mathematical equations describing combustion are based on the equations of conservation of mass, momentum, and energy together with equations for turbulence and combustion. The convergence criteria are set to $10^{-6}$ for the continuity, momentum, and turbulent kinetic energy dissipation rate of the turbulent kinetic energy, energy and the radiation equations and the mixture fraction.

The sheer-stress transport (SST) k-omega model is used to simulate the turbulent isothermal flow.. The SST k- $\omega$ model has the advantage in performance over the standard $\mathrm{k}-\varepsilon$ and the standard k- $\omega$ model. The model equations behave appropriately in the nearwall and far-field zones [45,46]. Then, the equations for the turbulence kinetic energy, $\mathrm{k}$, and the specific dissipation rate, $\omega$, are solved.

The non-premixed combustion with inlet diffusion model is used for modeling combustion. Equation for the conserved scalar (f) is solved. The P-1 radiation model is used to model radiation from the flame. The $\mathrm{P}-1$ radiation model is the simplest case of the P-N model. The formation of prompt nitric oxide (NO) was included in the calculations and the formation of thermal NO is modelled supposing that all nitrogen in the fuel is released as hydrogen cyanide $(\mathrm{HCN})$, then further reacts forming $\mathrm{NO}$ or molecular nitrogen $\mathrm{N} 2$ depending on the combustion conditions. Soot distribution within the combustor is calculated using the two step soot model with soot-radiation interaction. 


\section{The Numerical Solution}

The numerical solution is performed and the results are displayed using Ansys Fluent12. Different algorithms are used to solve the governing equations. The Semi Implicit Method for Pressure Linked Equations (SIMPLE) algorithm is used for pressure/velocity coupling. This algorithm satisfies the mass conservation equation by using a relationship between velocity and pressure corrections. Solution procedures are as follows: (1) completing calculation of the PDF look-up table, (2) starting the reacting flow simulation to determine the flow fields and predict the spatial distribution of the mixture fraction, (3) continue the reacting flow simulation until a convergence solution is achieved, and (4) determine the corresponding values of the temperature and individual chemical species mass fractions from the look-up tables. Multiple species including radicals and intermediate species, may be included in the problem definition and their concentrations may be derived from the predicted mixture fraction using assumption of equilibrium chemistry. Property data for the species are accessed through chemical database and turbulence-chemistry interaction is modeled using a beta-PDF.
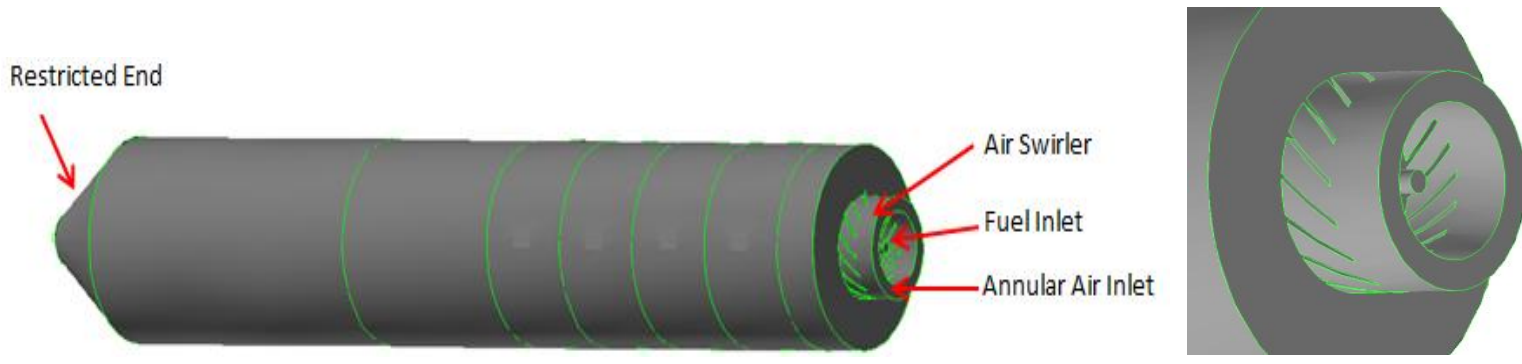

Figure (1) Generated geometry of the can combustor model and the air swirler

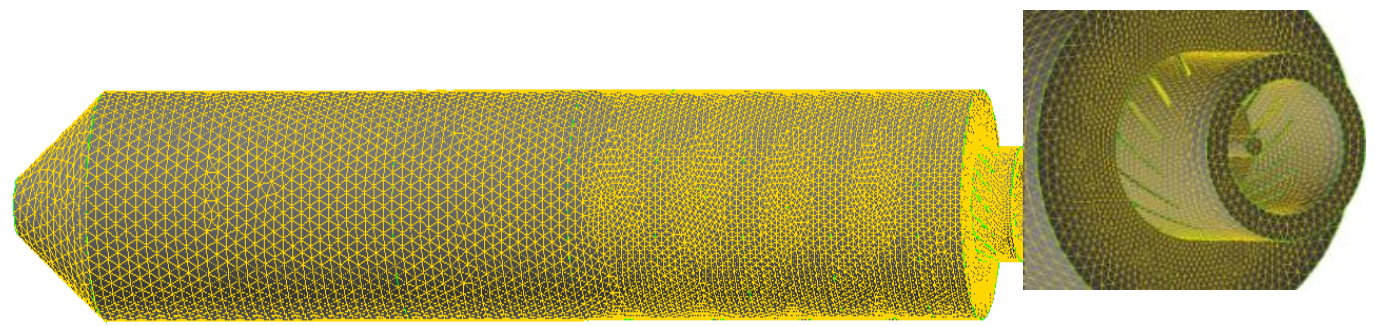

Figure (2) The Computational mesh of the combustor model and the air swirler

\section{4- Mesh independency study}

In order to obtain a grid-independent solution, the grid should be refined until the solution no longer varies with additional grid. The effect of mesh refinement on the solution is performed for combustion air mass flow of $100 \mathrm{~g} / \mathrm{s}$ and the cell number of the examined meshes are from 100,000 up to 400,000. The axial velocities along the combustor centerline are calculated for the studied mesh sizes. These show good agreement of axial velocities for 300000 and 350,000 mesh sizes while the other results are far. Therefore, the mesh size of 300,000 cells can provide sufficiently grid independent and accurate solution as shown in figure (3). 


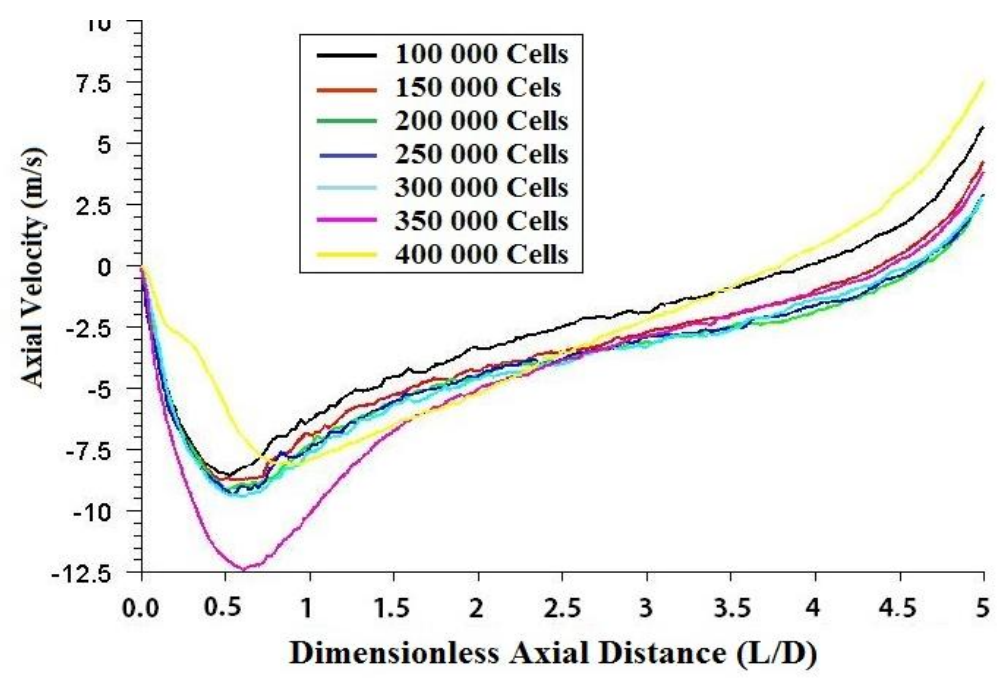

Figure (3) Mesh independency study

\section{Model Validation}

To validate the model, the computational results are compared with the experimental measurements using natural gas fuel as referred to reference [47]. The computational and experimental centerline temperature distributions are compared as shown in figure (4). The comparison shows a satisfactory and acceptable agreement with maximum error of about $8 \%$. The temperature levels obtained from computations are higher than that obtained from the experimental measurements. This is due to that the test combustor is water cooled, which absorbs quantitative amounts of heat, and further heat is lost by convection and radiation. In addition, using a bare wire thermocouple cooled by water, its junction does not obtain the same temperature of the combustion gases. Therefore, the measured temperatures are quite far from the calculated ones. Details of the experimental test rig are found in reference [47].

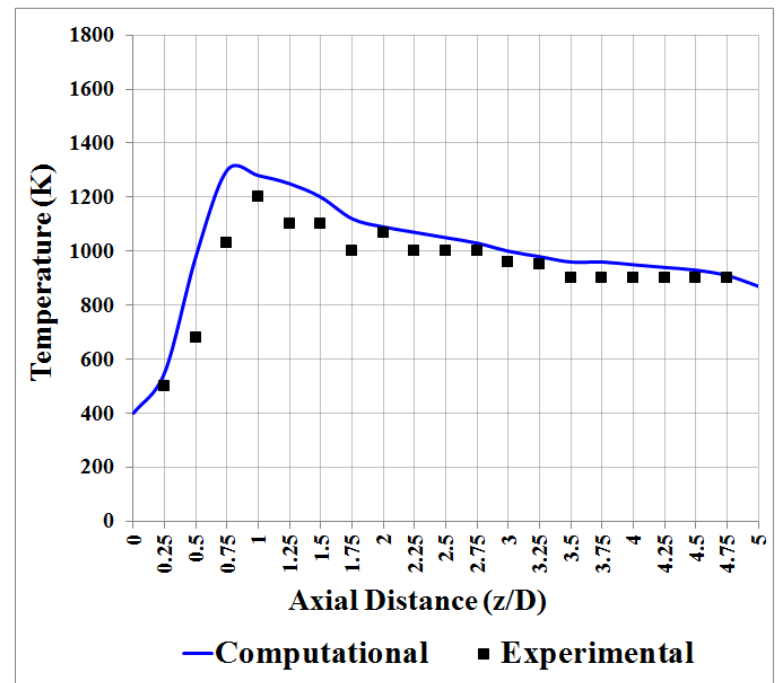

Figure (4) Numerical model validation by comparing the numerical results with the experimental temperature measurements for $\mathrm{A} / \mathrm{F}=30, \mathrm{~S}=0.5[47]$

\section{6-Results and discussion}

There are many reasons for alternative fuels used in jet aircraft to be developed. One of the most promising alternative fuels for the short term is natural gas. Natural gas has high energy content and has lower gravimetric density than Jet A-1. These differences cause several effects when it is mixed with aviation fuel to use in aircrafts. Air to fuel ratio of 40 is appropriate to obtain suitable flame size to study using the present combustor [47]. Results from the numerical investigation include the effect of swirl number on cold flow field, effect 
of swirl number on temperature maps of natural gas flame, and effect on temperature maps and emissions using different mixtures of natural gas and aviation fuels. Natural gas quantities included in the investigation are: $10 \%, 25 \%, 50 \%, 75 \%$, and $100 \%$.

It is shown from figure (5) that increasing the swirl number from 0.5 up to 1.1 leads to an increase in the recirculation zone size and accordingly the reverse flow zone sizes. It is also shown that as the swirl number increases, the reverse flow size becomes more attached to the upstream direction causing a decrease in flame length. Figure (5) shows also that high values of negative velocities increase as the swirl number increases while those of low negative velocities decrease as the swirl number increase. Higher swirling flows creates internal recirculation zone that circulates hot products to combustor upstream section. This plays an important role in mixing, improving flame stability and lowering the exhaust gases emissions. As swirl number increases the velocity range near zero decrease and the maximum negative velocity increases.
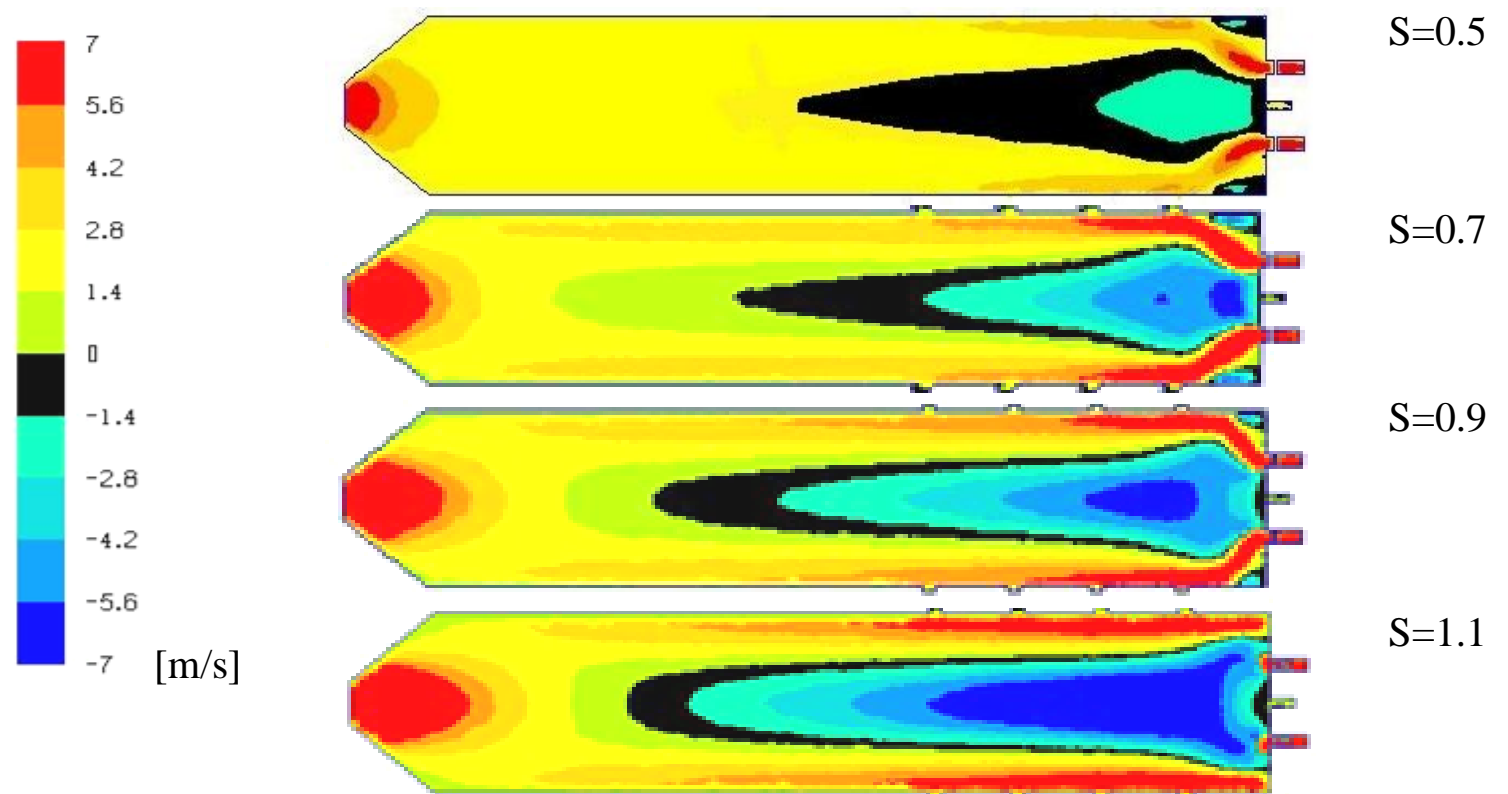

Figure (5) Axial Velocity Distribution and RFZ Boundaries inside it
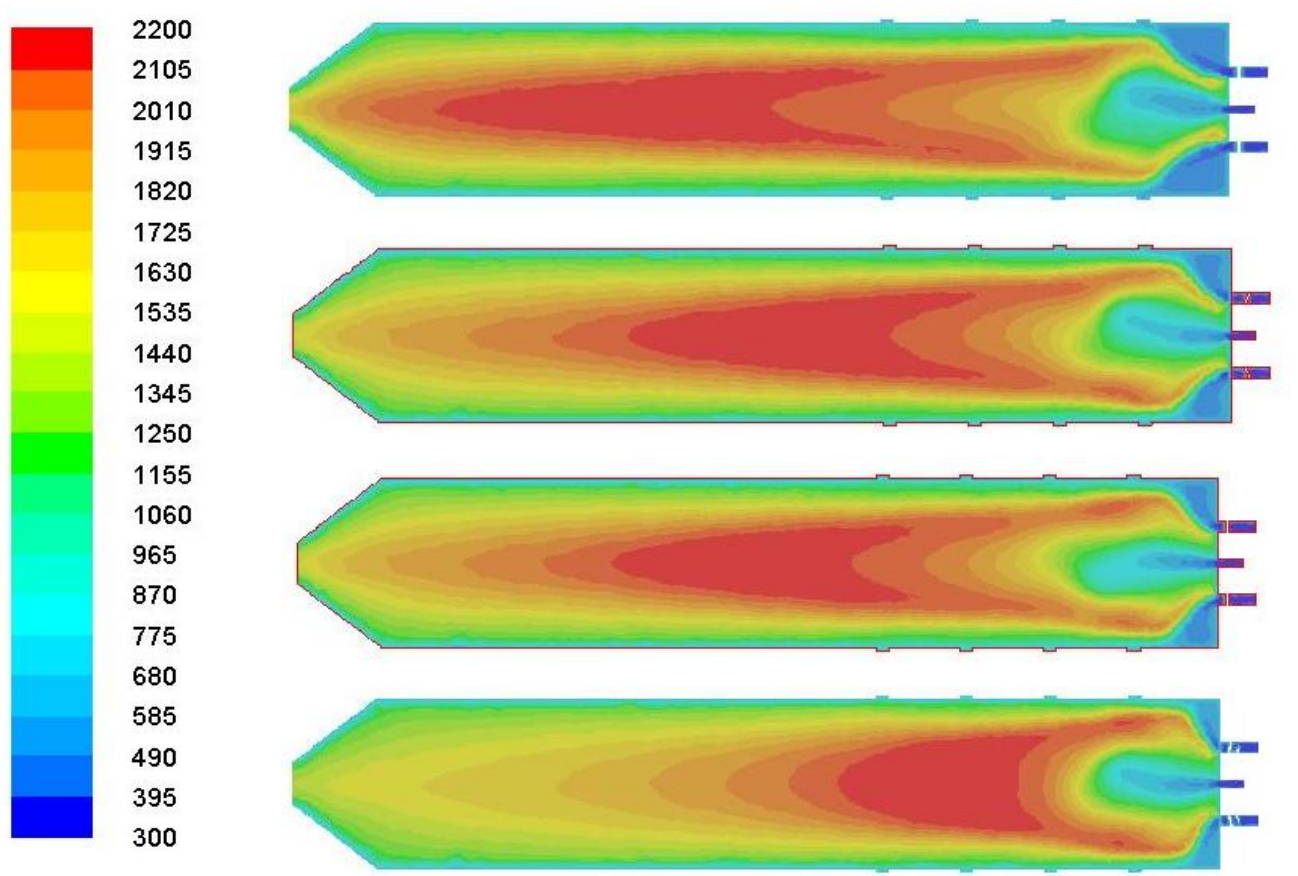

$\mathrm{S}=0.5$

[Weak]

$\mathrm{S}=0.7$

[Moderate

$\mathrm{S}=0.9$

[High]

$\mathrm{S}=1.1$

[Strong]

Figure (6) Effect of swirl numbers on temperature maps of natural gas flames [AF=30] 
From figure (6), it is shown from the temperature maps that as the swirl number increase, then the temperature levels are decreased and move to the upstream direction. Also the sizes of the high temperature regions are decreased and move to the upstream direction. This indicates that the flame length is decreased as the swirl number increases and also the high temperatures in the flame move near the swirler exit and the flame becomes wider in diameter. So, from the numerical investigation, there is a remarkable effect when using different air swirl numbers on temperature maps as shown $\mathrm{n}$ figure put below.

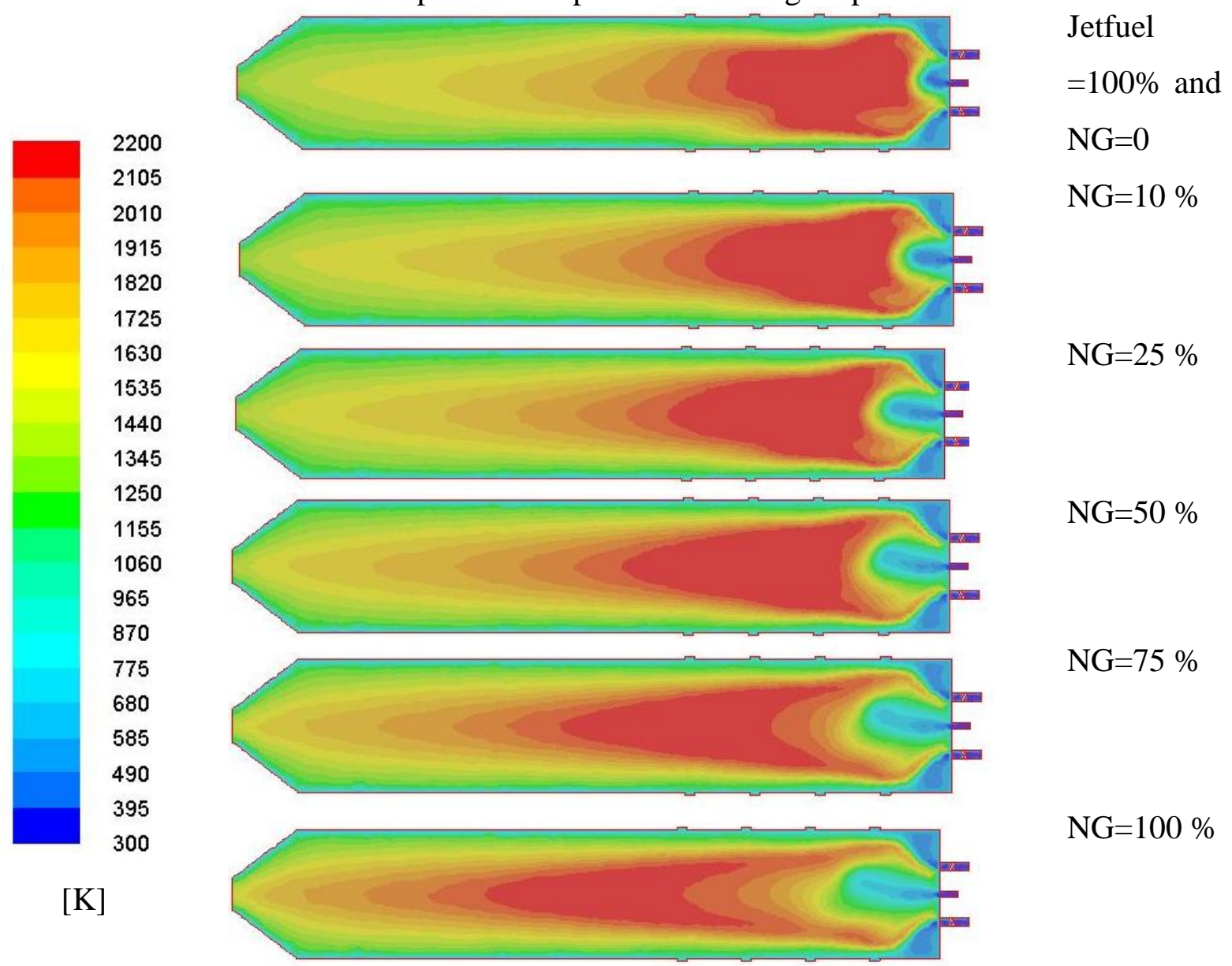

Figure (7) Effect of using jet-A, and natural gas fuel mixtures on

temperature maps $[\mathrm{S}=0.7 \& \mathrm{AF}=30]$

The $\mathrm{A} / \mathrm{F}$ ratio with relatively small amount of 20 produces flames with larger sizes, it is found that flames suitable for the present combustor are obtained with $A / F$ ratio=30 \& moderate swirl number of 0.7 [S>6]. Figure (7) shows effect of using jet-A, and natural gas fuel mixtures on temperature maps for swirl number of 0.7 and air to fuel ratio of 30 . It is shown from the figure that as the nature gas percent in the mixture increases from $10 \%$ up to $75 \%$, the flame length is also increased and the high temperature regions in the flame becomes farther from the swirler. Also for $100 \%$ natural gas the flame length increases more and the high temperature region move farther and the flame diameter becomes narrower. Generally, flame length and regions of high temperatures are increased as natural gas percent increases due to the improved mixing and increased combustion efficiency. Temperature maps for natural gas flame indicate that the high temperature region size is decreased and shifted downstream due to buoyancy effect of natural gas and its high flame speed.

Figure (8) shows that the effect of using mixtures of jet-A and natural gas fuels on axial temperature distrbutions along the combustor centerlne has different trends at the first half of the combustor from that at the second half of the combustor. for all mixtures, the temperatures 
are increased with the axiaal distance along the first part of the combsutor at $(0 \leq x / D \leq 2)$ and decrease at the second part at $(2 \leq \mathrm{x} / \mathrm{D} \leq 5.5)$. it is shown that as natural gas percent increase in the mixture, the temperature levels decrease at $(0 \leq \mathrm{x} / \mathrm{D} \leq 2)$. As natural gas percent increases, the temperature levels increase at $(2 \leq \mathrm{x} / \mathrm{D} \leq 5)$. The temperature levels decrease with higher rate for all mixture at the combustor end $(5 \leq \mathrm{x} / \mathrm{D} \leq 5.5)$ due to the effect of restricted end.

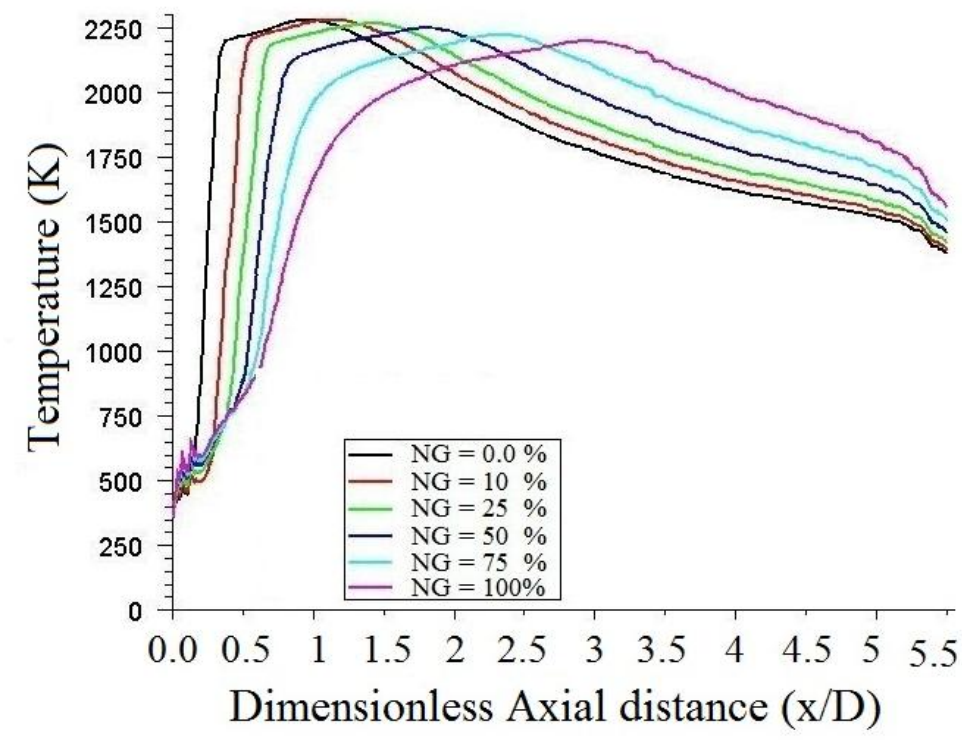

Figure (8) Effect of using jet-A, and natural gas fuel mixtures on axial temperature distrbutions along the combustor centerlne $[\mathrm{S}=0.7 \& \mathrm{AF}=30]$

Figure (9) shows that in the upstream section of the combustor, $\mathrm{CO}$ is decreased as the natural gas percent increases. At the second part of the combustor, $\mathrm{CO} 2$ increases with increasing natural gas percent. Near the combustor exit, $\mathrm{CO}$ tends to zero because of the restricted end.

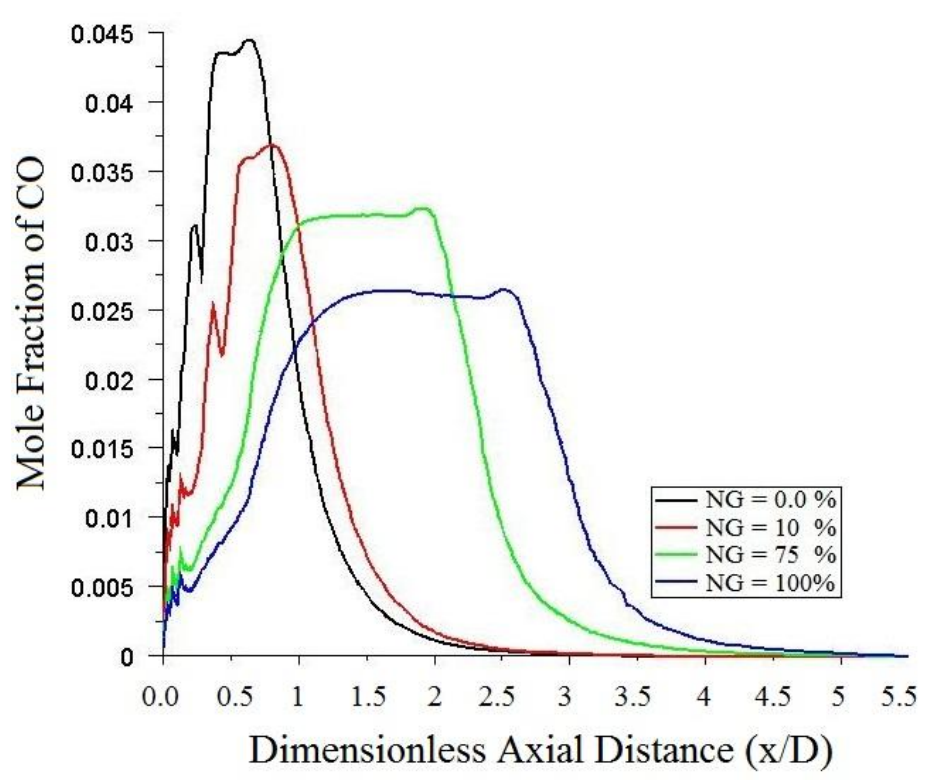

Figure (9) effect of using jet-A, and natural gas fuel mixtures on axial concentrations of mole fraction of $\mathrm{CO}$ species $[\mathrm{S}=0.7 \& \mathrm{AF}=30]$

Figure (10) shows the effect of natural gas and aviation-a fuel mixtures on axial concentrations of $\mathrm{CO} 2$. At the first half of the combustor, it is shown that as natural gas percent increases, the $\mathrm{CO} 2$ decreases $(0 \leq \mathrm{x} / \mathrm{D} \leq 3)$. At further downstream part of the combustor $((3 \leq \mathrm{x} / \mathrm{D} \leq 4.4), \mathrm{CO} 2$ values are nearly the same but near the combustor exit $\mathrm{CO} 2$ is decreased with increasing natural gas percent. 


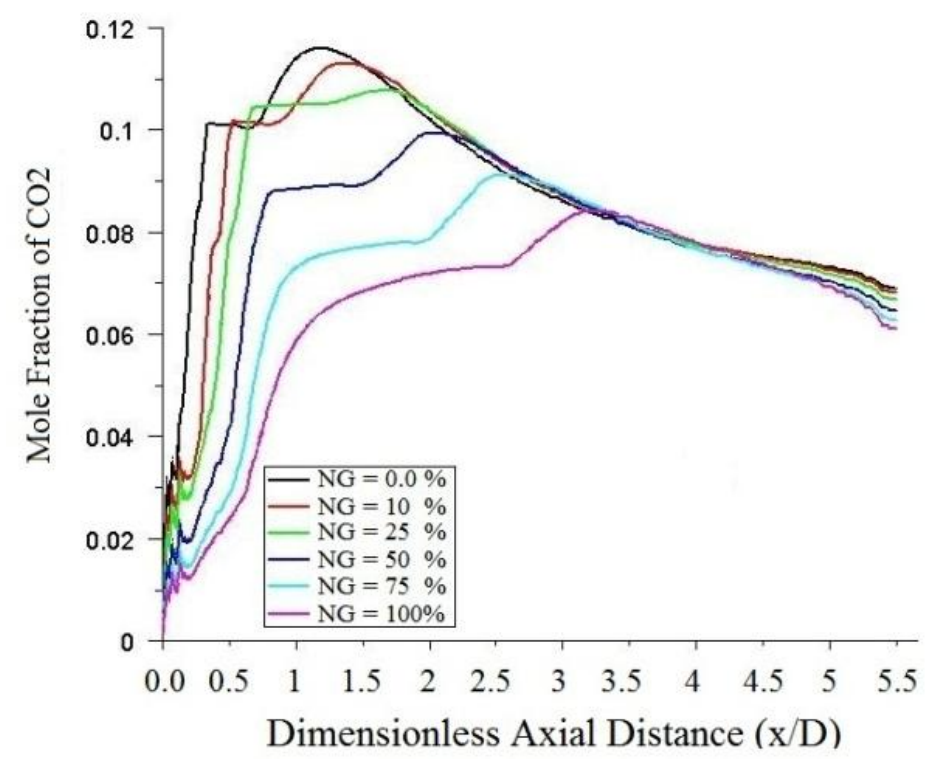

Figure (10) effect of using jet-A, and natural gas fuel mixtures on axial concentrations of mole fraction of $\mathrm{CO} 2$ species $[\mathrm{S}=0.7 \& \mathrm{AF}=30]$

Figure (11) shows that as a natural gas percent increases, the unburned jet-a in the fuel mixture tend to decrease slower rate and has a value close to zero but at lower percent of natural gas jet-a becomes nearly zero.

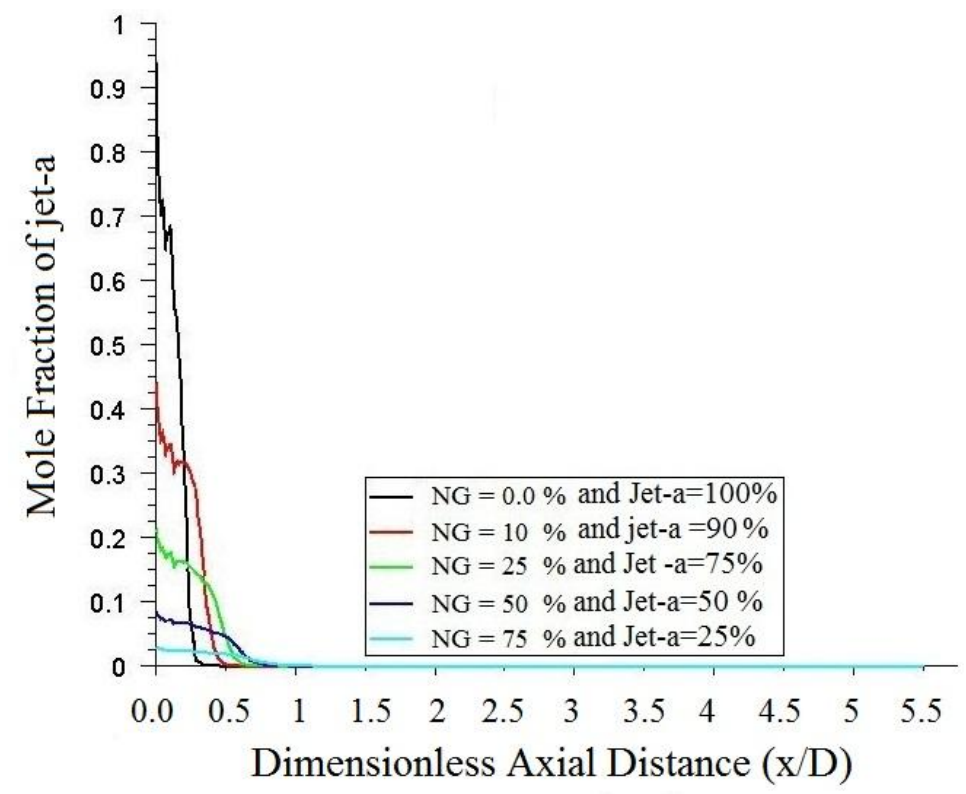

Figure (11) effect of using jet-A, and natural gas fuel mixtures on axial concentrations of mole fraction of jet-A species $[\mathrm{S}=0.7 \& \mathrm{AF}=30]$

From figure (12), it is shown that as N2 is increased rapidly for all mixtures at the combustor upstream at $(0 \leq x / D \leq 1)$ and the remains nearly constant along the most of the combustor length. $\mathrm{N} 2$ is decreased with increasing the natural gas percent for all mixtures. 


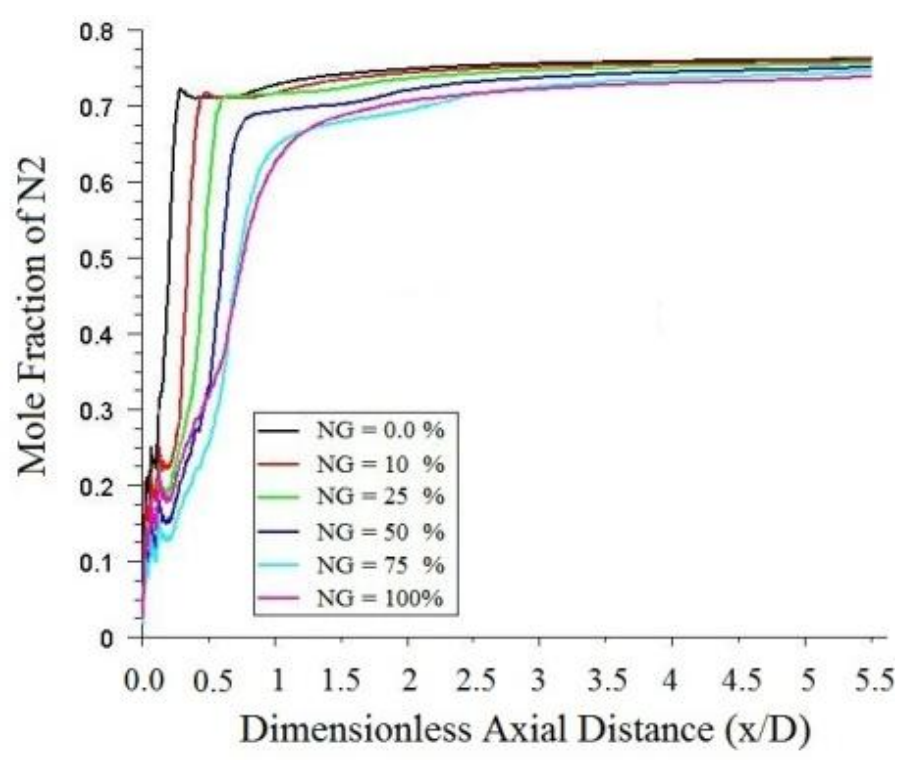

Figure (12) effect of using jet-A, and natural gas fuel mixtures on axial concentrations of mole fraction of $\mathrm{N} 2$ species $[\mathrm{S}=0.7 \& \mathrm{AF}=30]$

Figure (13) shows that soot volume fraction levels are decreased with increasing natural gas percent at the combustor upstream section $(0 \leq \mathrm{x} / \mathrm{D} \leq 0.5)$ and it is increased with increasing natural gas at the combustor end. This is because natural gas diffusion flame is sooty by its nature. Generally, Soot emissions for mixtures of natural gas with Jet-A show that increasing natural gas leads to increase in soot concentration.

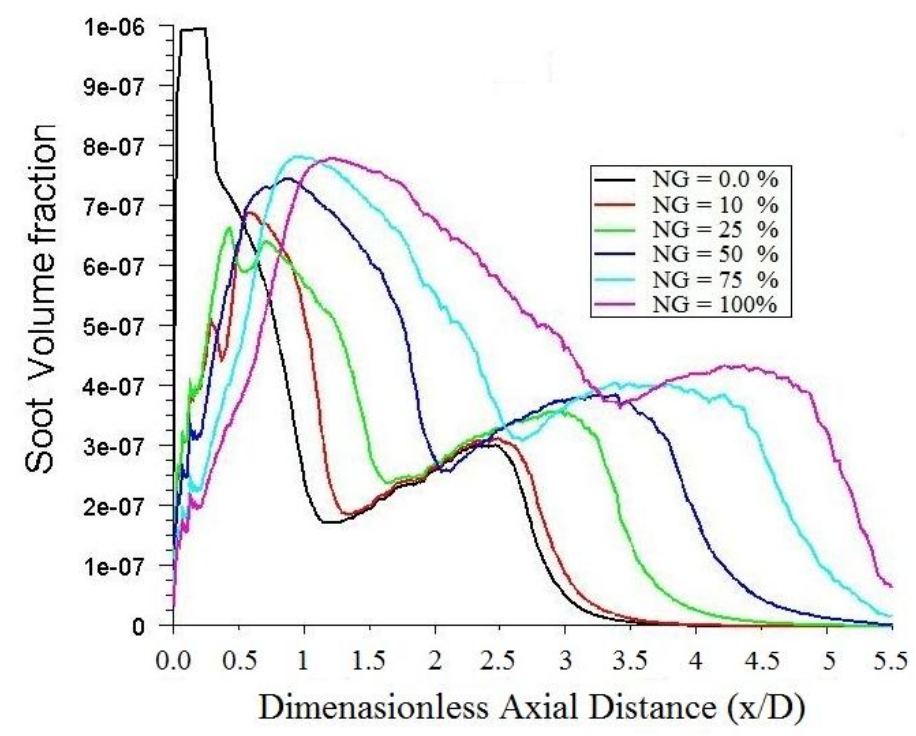

Figure (13) effect of using jet-A, and natural gas fuel mixtures on axial concentrations

$$
\text { of soot volume fraction }[S=0.7 \& A F=30]
$$

\section{Conclusions}

The present work is directed to investigate the flow aerodynamics, combustion and emissions characteristics within swirl gas turbine combustor. The coupling between fluid dynamics and combustion within the gas turbine combustor provides a major factor governing exhaust emissions. The formation and the size of the recirculation zone as a tool for exhaust emissions reduction are examined in the present study. From the preent results, the following conclusions are obtained: 
1-In non-reacting flow, the central recirculation zone has larger size compared to corner recirculation zone as a result of highly swirling flow and vice-verse for low swirl flow.

2-High turbulence levels are achieved within the combustor dome due to the swirling effects.

3- The high levels of turbulence and the resulting good mixing of fuel with air explain the success of the air swirler to produce uniform temperature distribution within the gas turbine combustor and low exhaust emissions.

4-The recirculation zone tends to be longer and wider with increasing the swirl number especially at upstream section.

5-The swirl number may not be the correct parameter to characterize the properties of the recirculation zone while sufficient swirl is needed to recirculate the flow.

6- The flow aerodynamics can play a significant role in either decreasing exhaust species concentrations based on their location and strength.

7-Maximum UHC are found near the combustor upstream before that of the CO. Maximum $\mathrm{N} 2$ concentrations are found farther downstream of $\mathrm{CO}$ and UHC maximums.

\section{References}

[1] Guenther C. Krieger, Andre P. V. de Campos, Fernando L. Sacomano Filho, Rafael C. de Souza, "A swirler stabilized combustion chamber for a micro-gas turbine fuelled with natural gas”, J. Braz. Soc. Mech. Sci. \& Eng. vol.34 no.4 Rio de Janeiro Oct./Dec. (2012)

[2] P. Sravan Kumar and P. Punna Rao, "Design and Analysis of Gas Turbine Combustion Chamber", International Journal Of Computational Engineering Research (ijcer) Vol. 03 Issue 12 (December 2013) 36:40.

[3] Ahmed I. Farag,"A study of secondary air effect on natural gas combustion characteristics" $\mathrm{Ph}$. D. thesis, college of engineering, port said university, (2012).

[4] Firoj, H. P., Nikul, K. P., Mihir, V. T., " Numerical Investigation of the Combustion of Methane Air Mixture in Gas Turbine Can-Type Combustion Chamber", International Journal of Scientific \& Engineering Research, Volume 3, Issue 10, (2012)

[5] Gupta, A. K., Lilley, D. G., and Syred, N., Swirl flows, Abacus Press, 1984.

[6] William Allan, Marc La Violette and Pierre Poitras, "Emissions From a Gas Turbine Sector Rig Operated With Synthetic Aviation and Biodiesel Fuel", Journal of Engineering for Gas Turbines and Power, Volume 133, Issue 11, (May, 2011).

[7] Eldrainy, Y.A., Saqr, K.M., Aly, H.S., Nazri Mohd J.M., "CFD insight of the flow dynamics in a novel swirler for gas turbine combustors", International Communications in Heat and Mass Transfer 36, 936 - 94, (2009).

[8] Mark, D.T., Philip, J.S., Syed, K. J., and Eoghan, B., "CFD Simulation of the Flow Within and Downstream of a High Swirl Lean Premixed Gas Turbine Combustor", Proceedings of ASME Turbo Expo 2004 Power for Land, Sea, and Air, June 14-17, (2004), Vienna, Austria, GT2004-53112

[9] Thiago, K.A., Carlo E.F., Karolline R., Da Silva, L.F., and Luis Enrique A. H., "CFD analysis of an inducstrial gas turbine combustion chamber", $13^{\text {th }}$ Brazilian Congress of Thermal Sciences and Engineering December 05-10, 2010, Uberlandia, MG, Brazil

[10] Shaik, M.H., Sudheer, P.K., Vijaya, K.R., "CFD analysis of combustion and emissions to study the effect of compression ratio and biogas substitution in a diesel engine with experimental verification", International Journal of Engineering Science and Technology (IJEST).

[11] ABDALLAHABOU-TAOUK, "CFD Modeling of Combustion in Flexi-Fuel Burners at Gas Turbine Conditions", Division of Fluid Dynamics, Department of Applied Mechanics CHALMERS UNIVERSITY OF TECHNOLOGY, Goteborg, Sweden, (2011).

[12] Mongia, H.C., "A Fourth Generation Propulsion Combustor Technology for Low Emissions," AIAA International Air and Space Symposium and Exposition: The Next 100 Years , 2003. 
[13] Mongia, H.C., "A Fourth Generation Propulsion Combustor Technology for Low Emissions," AIAA International Air and Space Symposium and Exposition: The Next 100 Years , 2003.

[14] Nima Mirzamohammad, Omid Razbani, and Mohsen Assadi, "Review of theoretical and experimental studies implemented on (CHP) Micro turbine using natural gas and biogas fuels", Third International Conference on Applied Energy - 16-18 May 2011 - Perugia, Italy

[15] Naitik H. Gor and Milan J. Pandya, "CFD Analysis of Swirl Can Combustion Chamber- A Review", IJIRST-International Journal for Innovative Research in science7technology, Volume 1, issue 61 November, 2014.

[16] Fagner Luis Goular Dias, Marco Antonio Rosa do Nascimento, Lucilene de Oliveira Rodrigues, "Reference Area Investigation in a Gas Turbine Combustion Chamber Using CFD”, Journal of Mechanical Engineering and Automation 2014, 4(2): 73-82 DOI: 10.5923/j.jmea.20140402.04

[17] Dong-Sik Han, Gyu-Bo Kim, Han-Suk Kim, and Chung-Hwan Jeon, "Experimental study of NOx correlation for fuel staged combustion using lab-scale gas turbine combustor at high pressure", Experimental thermal and fluid science 58-2014:62-69

[18] Mendez, C.J., Parthasarathy, R.N. and Gollahalli, S.R., "Performance and emission characteristics of butanol/Jet A blends in a gas turbine engine", Applied Energy, Volume 118 (c ):pages 135-140, 2014.

[19] Lefebvre, A. H., "Pollution Control in Continuous Combustion Engines", Proceedings of the Combustion Institute, Vol. 15, 1975, pp. 1169-1180.

[20] Stouffer, S. D., Ballal, D. R., Zelina, J., Shouse, D. T., Hancock, R. D., and Mongia, H. C., "Development and Combustion Performance of a High-Pressure WSR and TAPS Combustor," AIAA Paper 2005-1416, January 2005

[21] Tacina, R.R., "Combustor Technology for Future Aircraft," AIAA Paper1990-2400, July 1990.

[22] Penner, J. E., Lister, D. H., Griggs, D. J., Dokken, D. J., and McFarland, M., Aviation and the global atmosphere, Cambridge University Press, Cambridge, United Kingdom, 1999.

[23] Lefebvre, A. H., Gas Turbine Combustion, 2ed., Taylor and Francis, Philadelphia, PA, 1998.

[24] Syred, N. and Beér, J. M., "Combustion in Swirling Flows: A Review," Combustion and Flame, Vol. 23, 1974, pp. 143-201.

[25] Sloan, D. G., Smith, P. J., and Smoot, L. D., "Modeling of Swirl in Turbulent Flow Systems," Progress in Energy and Combustion Science, Vol. 12, 1996, pp. 163-250.

[26] Beer, J.M. and Chigier N., "Combustion Aerodynamics", Applied Science Publishers LTD, London, 1972.

[27] Lucca-Negro, O. and O'Doherty, T., "Vortex Breakdown: A Review," Progress in Energy and Combustion Science, Vol. 27, 2001, pp. 431-481.

[28] Chigier, N. and Beér, J. M., "The Flow Region Near the Nozzle in Double Concentric Jets," Journal of Basic Engineering, Vol. 86, No. 4, 1964, pp. 797-804.

[29] Chigier, N. and Chervinsky, A., "Experimental Investigation of Swirling Vortex Motion in Jets," Journal of Applied Mechanics, Vol. 34, 1967, pp. 443-451.

[30] Tangirala V., Chen, R.H., and Driscoll, J.F., "Effect of Heat Release and Swirl on the Recirculation within Swirl-Stabilized Flames," Combustion Science and Technology, Vol. 51, 1987, pp. 75-95.

[31] Bulzan, D. L., "Structure of a Swirl-Stabilized Combusting Spray," Journal of Propulsion and Power, Vol. 11, No. 6, 1995, pp. 1093-1102.

[32] Bornstein, J. and Escudier, M. P., "LDA Measurements within a Vortex-Breakdown Bubble," International Symposium on Applications of Laser-Doppler Anemometry to Fluid Mechanics , 1982, pp. 1-11.

[33] Vu, B. T. and Gouldin, F. C., "Flow Measurements in a Model Swirl Combustor," AIAA Journal, Vol. 20, No. 5, 1982, pp. 642-651. 
[34] Bowman, C. T., "Kinetics of Pollutant Formation and Destruction in Combustion," ogress in Energy and Combustion Science, Vol. 1, 1975, pp. 33-45.

[35] Kenbar, A. M. A., Beltagui, S. A., Ralston, T., and MacCallum, N. R. L., "Measurement and Modeling of NOx Formation in a Gas Fired Furnace," Combustion Science and Technology, Vol. 93, 1993, pp. 173-192.

[36] Chen, R.-H. and Driscoll, J. F., "Nitric Oxide Levels of Jet Diffusion Flames: Effects of Coaxial Air and Other Mixing Parameters," Proceedings of the Combustion Institute , Vol. 23, 1990, pp. 281-288.

[37] Schmittel, P., Günther, B., Lenze, B., Leuckel, W., and Bockhorn, H., "Turbulent Swirling Flames: Experimental Investigation of the Flow Field and Formation of Nitrogen Oxide," Proceedings of the Combustion Institute, Vol. 28, 2000, pp. 303309.

[38] Mellor, A.M., Anderson, R.D., Altenkirch, R. A., and Tuttle, J. H., "Emissions from and within an Allison J-33 Combustor," Combustion Science and Technology, Vol. 6, 1972, pp. 169-176.

[39] Claypole, T. C. and Syred, N., "The Effect of Swirl Burner Aerodynamics on NOx Formation," Proceedings of the Combustion Institute, Vol. 18, 1981, pp. 81-89.

[40] Correa, S. M., "Carbon Monoxide Emissions in Lean Premixed Combustion," Journal of Propulsion and Power. Vol.8, No. 6, 1992, pp. 1144-1151.

[41] Baulch, D. L. and Drysdale, D. D., "An Evaluation of the Rate Data for the Reaction + H, $\mathrm{CO}+\mathrm{OH}$--> CO " Combustion and Flame, Vol. 23, 1974, pp. 215-225.

[42] Bowman, C.T. "Chemistry of Gaseous Pollutant Formation and Destruction", Fossil Fuel Combustion, Wiley \& Sons, New York, 1991, pp. 215-260.

[43] Westenberg, A.A. and deHaas, N., "Steady State Intermediate Concentrations and Rate Constants HO Results," Journal of Physical Chemistry, Vol. 76, No. 11, 1972, pp. 15861593.

[44] GAMBIT Program User Guide, September (2006)

[45] Tobias Knopp, Bernhard Eisfeld and Javier Bartolome Calvo, 2009, “A new extension for $\mathrm{k}-\omega$ turbulence models to account for wall roughness", International Journal of Heat and Fluid Flow 30, pp. 54-65

[46] Jonas Bredberg, Shia-HuiPeng, Lars Davidson, 2002, “An improved k- $\omega$ turbulence model applied to recirculating flows", International Journal of Heat and Fluid Flow, 23, pp.731743

[47] Akram Zaid and Ahmed Farag "Effect of Secondary Air Configuration in Gas Turbine Combustor Firing Natural Gas", Proceedings of ASME 2014 International Mechanical Engineering Congress \& Exposition IMECE2014, Nov. 14-20, 2014, Montreal, Canada. 